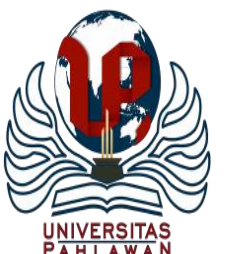

UNIVERSITAS

\title{
Kebijakan Standar Pembiayaan Di Sekolah Dasar
}

\author{
Septiana Aisyiah ${ }^{1}$, Sufyarman Marsyidin ${ }^{2}$, Ahmad Sabandi $^{3}$ \\ Universitas Negeri Padang, Sumatera Barat, Indonesia ${ }^{1,2,3}$ \\ E-mail: septianaaisyiah@gmail.com ${ }^{1} \underline{\text { sufyarma1954@gmail.com }{ }^{2}} \underline{\text { sabandi @fip.unp.ac.id }^{3}}$
}

\begin{abstract}
Abstrak
Tujuan pembahasan ini adalah untuk mengetahui kebijakan pembiayaan di SD. Metode kepustakaan (library research) digunakan sebagai metodologi penelitian dalam penelitian ini. Teknik pengumpulan data dalam pembahasan ini yaitu dengan mengkaji atau mengeksplorasi beberapa buku, jurnal serta dokumen lain yng dianggap relevan. Penelitian ini membahas tentang hal yang penting dalam pengelolaan pembiayaan di SD. Pembiayaan di SD tidak lepas dari beberapa persen dari pendapatan APBD dan APBN. Pembiayaan di SD ini sangat erat hubungannya dengan dana BOS. Pada masing-masing sekolah itu berbeda jumlah uang yang didapatkan. Semua itu sesuai dengan keadaan jumlah siswa dan tingkatan pendidikannya. Semua itu sudah ada pada permendiknas yng sudah ditetapkan.
\end{abstract}

Kata kunci: pembiayaan, BOS, pendidikan

\begin{abstract}
The purpose of this discussion is to find out financing policies in elementary schools. The library research method is used as a research methodology in this study. Data collection techniques in this discussion is by reviewing or exploring several books, journals and other documents that are considered relevant. This study discusses the important things in the management of financing in elementary schools. Funding in elementary schools cannot be separated from a few percent of $A P B D$ and APBN revenues. Funding at this elementary school is very closely related to BOS funds. At each school the amount of money is different. All that is in accordance with the state of the number of students and their level of education. All of that already exists in the Ministry of Education which has been established.
\end{abstract}

Keywords: financing, BOS , education

Copyright (c) 2020 Septiana Aisyiah, Suryarma Marsidin, Ahmad Sabandi

$\triangle$ Corresponding author :

Address : Padang, Sumbar

Email : kurniapuspitasari248@gmail.com

ISSN 2656-8071 (Media Cetak)

Phone : 081276747068

ISSN 2656-8063 (Media Online)

DOI: $10.31004 /$ edukatif.v2i2.121 


\section{PENDAHULUAN}

Kualitas suatu negara dilihat dari pendidikannya. Oleh karena itu, untuk meningkatkan kemampuan dalam mengolah sumber daya alam harus dengan pendidikan. Koswara dan Triatna dalam (Azhari \& Kurniady, 2016a) menulis, dari dalam, luar dan masyarakat itu merupakan pengaruh mutu pendidikan. Dari dalam adalah bagus gurunya, siswanya, sarprasnya dan yng lain.

Menjamin mutu pendidikan adalah pembiayaan walaupun bukan itu saja, masih banyak lagi, namun kalau itu tidak ada maka itu hanya khayalan saja (Mulyono, 2009). Biaya yang digunakan untuk mutu sekolah atau pendidikan adalah BOS. Dana itu didapatkan dari beberapa tempat yang bertujuan untk meningkatkan sekolah atau pendidikan (Durotun Nafisah, $\square$ Widiyanto, 2013). Komponen yang penting dalam pendidikan adalah pembiayaan yaitu $20 \%$ dari APBD dan APBN.

Pembiayaaan pendidikan adalah jumlah uang yang dihasilkan dan dibelanjakan untuk berbagai keperluan penyelenggaraan mencakup: gaji guru, peningkatan 12 profesional guru, sarana, ruang belajar, perbaikan ruang, pengadaan peralatan/mebeleir, pengadaan alat-alat dan buku pelajaran, alat tulis kantor, kegiatan ekstrakurikuler, kegiatan pengelolaan pendidikan, dan supervisi pendidikan.

Pembiayaan sangat erat ada pada sekolah dasar adalah BOS, yang merupakan sebuah pembiayaan yang dari pemerintah bertujuan untuk memenuhi kebutuhan sekolah. Namun masingmasing sekolah dapat dana tersebut jumlahnya berbeda, disesuaikan dengan keadaan sekolah dan jumlah banyak siswa di sekolah itu. Tingkatan sekolahnya pun akan menerima dana tersebut berbeda.

Pembiayaan Pendidikan: Suatu Kajian Teortis segala tunjangan yang melekat pada gaji; bahan atau peralatan habis pakai; dan biaya operasi pendidikan tak langsung berupa daya, air, jasa telekomunikasi, uang lembur, transportasi, konsumsi, pajak, asuransi, dan lain sebagainya (Kompri, 2016).

Berdasarkan pemaparan diatas, karena pentingnya pemahaman tentang kebijakan soal pembiayaan di SD, maka diperlukan kajian studi perpustakaan untuk membahas hal tersebut. Untuk itu penulis tertarik dalam melakukan pembahasan dengan judul "Kebijakan Pengelolaan Pembiayaan di SD”. Tujuan pembahasan ini adalah mendeskripsikan kebijakan standar pembiayaan di $\mathrm{SD}$, dasar pengelolaan pembiayaan di SD dan Permendiknas yang berhubungan dengan pembiayaan di SD.

\section{METODE PENELITIAN}

Pada tulisan ini metode yng digunakan adalah metode tinjauan pustaka (library research). Metode ini dilakukan dengan mengumpulkan berbagai bacaan dari berbagai sumber. (Harahap, 2014). Data yang digunakan dalam menyelesaikan penelitian ini berasal dari sumber berupa buku, jurnal serta artikel yang sesuai dengan penilitian ini.

\section{HASIL DAN PEMBAHASAN PENELITIAN}

Pengertian standar pembiayaan di SD

Sistem biaya pendidikan adalah sebuah kegiatan pengelolaan keuangan yang 
digunakan untuk kegiatan sekolah. Sistim biaya tergantung kepada keadaan negara dan situasi sekolah.

Kegiatan itu berhasil, dapat dilihat dalam berbagai aspek pendidikan. Setiap keputusan dalam masalah pembiayaan sekolah akan berpengaruh terhadap penghasil yang diberikan dan didapatkan (Azhari \& Kurniady, 2016b). Oleh karena itu, ditinjau dari faktor dari tendik dan biaya pendidikan dan tindakan yang bagus untuk membuat ke depan pendidikan. Pembiayaan sekolah tidak sama diberbagai daerah sesuai situasi dan kondisi daerah itu (Simkins, 2013).

Pembiaayan sekolah ini bekaitan dengan bidang politik pendidikan dan program pembiaayan pemerintah serta administrasi sekolah. Beberapa istilah yang sering digunakan dalam pembiaayan skolah, yakni school revenues, school expenditures, capital dan current cost. Dalam pembiayaan sekolah tidak ada pendekatan tunggal dan yang paling baik untuk pembiayaan semua sekolah karena kondisi tiap sekolah berbeda.

Setiap kebijakan dalam pembiayaan sekolah akan mempengaruhi bagaimana sumber daya diperoleh dan dialokasikan. Dengan mengkaji berbagai peraturan dan kebijakan yang berbeda-beda di sektor pendidikan, maka akan tampak konsekuensinya terhadap pembiayaan pendidikan (Simkins, 2013), yakni: keputusan tentang siapa yang akan dididik dan seberapa banyak jasa pendidikan dapat disediakan, keputusan tentang bagaimana mereka akan dididik, keputusan tentang siapa yang akan membayar biaya pendidikan, keputusan tentang sistem pemerintahan seperti apa yang paling sesuai untuk mendukung pembiayaan sekolah.

$$
\text { Banyak yang dilakukan dalam }
$$
pembiayaan di sekolah, hasilnya akan berbeda. Hasil pendidikan berbeda dari peraturan berbeda (Simkins, 2013), yakni tentang semua faktor yang dapat mendukung pendidikan yang bagus, baik itu tendik, biaya dan sarpras sekolah.

\section{Konsep Dasar Pengelolaan Pembiayaan di SD}

Lembaga pendidikan memperoleh manusia berkualitas melalui pendidikan. Definisi biaya ada empat yaitu : ekonomi, satuan uang, prospek ke depan, untuk tujuan tertentu. BOS merupakan dana untuk kelancaran pendidikan sekolah baik itu secara kegiatan sekolah ke pembelajaran atau tidak pembelajaran.

Biaya oprasional pendidikan adalah bagian dari dana pendidikan yang diperlukan untuk membiayai kegiatan operasional satuan pendidikaan agar kegiatan pendidikan dapat berlangsung sesuai standar nasional pendidikan secara teratur dan berkelanjutan yang terdiri atas biaya operasi kepersonaliaan dan biaya operasi non kepersonaliaan. Sekolah memerlukan adanya pembiayaan oprasional pendidikan yang diperoleh dari sumber-sumber yang telah ditentukan demi kelancaran kegiatan pendidikan.

Pembiayaan itu bagi manusia sebenarnya, ada di UUD 1945 pasal 31 
"setiap warga negara berhak mendapat pengajaran." Kondisi inilah kemudian mendorong dimasukannya klausal tentang pendidikan dalam perubahan UUD 1945, untuk pendidikan ada $20 \%$ dari APBD dan APBN.

Menurut (Nanang, 2006) terdapat tiga aspek keterlibatan pemerintah di pembiayaan pendidikan: pendidikan untuk manusia, orang tua dan faktor ekonomi.

\section{Isi Permendiknas Tentang Standar Pembiayaan di SD}

Standar pembiayaan dalam setahun ada pada PP 9/2005. Biaya itu semua yang mengeluarkan biaya dalam satu tahun. Standar Pembiayaan Pendidikan diatur berdasarkan Peraturan Menteri Pendidikan Nasional Nomor 69 Tahun 2009 tentang biaya untuk SD/MI, SMP/MTs, SMA/MA, SMK, SDLB, SMPLB, dan SMALB; Permendiknas Nomor 69 Tahun 2009 terdiri atas 4 pasal diantaranya: pasal 1 untuk biaya non-personal unuk lembaga pendidikan, pasal 2 untuk masih tentang biaya non-personal yang terlampir pada permen.

Biaya operasi satuan pendidikan sebagaimana dimaksud di atas meliputi:

a. gaji pendidik dan tendik serta segala tunjangan yang melekat pada gaji,

b. bahan atau peralatan pendidikan habis pakai, dan

c. biaya operasi pendidikan tak langsung berupa daya, air, jasa telekomunikasi, pemeliharan sarpras, uang lembur, transportasi, konsumsi, pajak, asuransi, dan lain sebagainya

Permendiknas lampiran I dan II, pasal 3 untuk yang belum memenuhi syarat biayanya lebih kurang dari standar, pasal 4 tentang petunjuk teknis BOS (Menteri Pendidikan dan Kebudayaan Republik Indonesia, 2020) yaitu penerimaan dana SD. SMP, SMA, SMK, SLB, jumlah dana persiswa, SD sebesar sembilan ratus ribu, SMP sebesar satu juta seratus ribu, SMA sebesar satu juta lima rastus ribu, SMK sebesar satu juta enam ratus ribu, SLB sebesar dua juta, uang itu untk: PPDB; pustaka; kegiatan pembelajaran dan ekstrakurikuler; kegiatan asesmen; administrasi kegiatan skolah; PPG dan tendik; daya dan jasa; sarpras; media pembelajaran; PKL; UKG, dan honor.

\section{KESIMPULAN}

Faktor penting untuk meningkatkan SDM bagus adalah pembiayaan. Dalam UUD 1945 pasal 31 "setiap warga negara berhak mendapat pengajaran." Sikon ini penyebab masuk ke UUD 1945. Pembiayaan tentang pendidikan ada di PP no 9/ 2005. PP19/2005 tentang SNP menjelaskan Standar pembiayaan adalah standar yang mengatur komponen dan besarnya biaya operasi satuan pendidikan yang berlaku selama satu tahun. Pembiayaan pendidikan terdiri atas biaya investasi, biaya operasi, dan biaya personal. Biaya investasi satuan pendidikan sebagaimana dimaksud di atas meliputi biaya penyediaan sarprtas, pengembangan sumber daya manusia, dan modal kerja tetap. Biaya personal sebagaimana dimaksud pada di atas meliputi biaya pendikan yang harus dikeluarkan 
157 Kebijakan Standar Pembiayaan Di Sekolah Dasar - Septiana Aisyiah, Sufyarman Marsyidin, Ahmad Sabandi DOI: 10.31004/edukatif.v2i2.121

oleh peserta didik untuk bisa mengikuti proses pembelajaran secara teratur dan berkelanjutan.

Untuk mengetahui keberhasilan program dengan cara: menghitung buta huruf; pembiayaan pendidikan yang adil untuk masyarakat. Setiap keputusan dalam masalah pembiayaan sekolah akan mempengaruhi bagaimana sumber daya diperoleh dan dialokasikan (Azhari \& Kurniady, 2016b).

\section{DAFTAR PUSTAKA}

Azhari, U. L., \& Kurniady, D. A. (2016a). Manajemen Pembiayaan Pendidikan, Fasilitas Pembelajaran, Dan Mutu Sekolah. Jurnal Administrasi Pendidikan, 23(2).

Azhari, U. L., \& Kurniady, D. A. (2016b). MANAJEMEN PEMBIAYAAN PENDIDIKAN, FASILITAS PEMBELAJARAN, DAN MUTU SEKOLAH. Jurnal Administrasi Pendidikan.

Durotun Nafisah, $\square$ Widiyanto, W. S. (2013). MANAJEMEN PEMBIAYAAN PENDIDIKAN DI MADRASAH ALIYAH. 2(1), 18-23.

Harahap, N. (2014). Penelitian Kepustakaan. Jurnal Iqra'. 8(1).

Kompri. (2016). Manajemen Pendidikan Komponen-Komponen ElementerKemajuan Sekolah. Jogjakarta: Ar-Ruzz Media.

Menteri Pendidikan dan Kebudayaan Republik Indonesia. (2020). Petunjuk Teknis Bantuan Operasional Sekolah Reguler. 1-17. Retrieved from jdih.kemdikbud.go.id

Mulyono. (2009). Manajemen Administrasi \& Organisasi Pendidikan. Yogyakarta: ArRuzz Media.

Nanang, F. (2006). Ekonomi \& Pembiayaan Pendidikan. Bandung: Remaja Rosdakarya.

Simkins, T. (2013). Educational reform and managerialism: Comparing the experience of schools and colleges. Educational
Management: Major Themes in Education, 2(April), 417-436. https://doi.org/10.4324/9780203463383 